\title{
Screening for Neuroblastoma
}

National Cancer Institute

\section{Source}

National Cancer Institute. Screening for Neuroblastoma. NCI Thesaurus. Code C15641.

The use of any device, marker, or other means for the purpose of detecting the presence of neuroblastoma, usually before there are symptoms. 